\title{
IMPLEMENTASI KEBIJAKAN SISTEM PELAPORAN KEUANGAN BERBASIS AKRUAL DI DPMPTSP KOTA PALOPO
}

\author{
Muh. Ginanjar ${ }^{1}$ \\ ${ }^{1}$ Fakultas Ekonomi dan Bisnis Islam, Institut Agama Islam Negeri Palopo., Palopo, Indonesia \\ Email: muh_ginanjar@iainpalopo.ac.id
}

\section{A R T I CLE I N F O}

\section{Article History:}

Received: 26 January 2021

Revised: 09 May 2021

Accepted: 24 May 2021

\section{Keywords:}

Sistem Pelaporan Keuangan;

Implementasi Kebijakan Pelaporan

Keuangan;

Akuntansi Berbasis Akrual;

Sistem Akuntansi

\begin{abstract}
A B S T R A C T
Tujuan penelitian ini adalah untuk mengetahui dan menganalisis implementasi sistem pelaporan keuangan berbasis akrual pada Dinas Penanaman Modal dan Pelayanan Terpadu Satu Pintu (DPMPTSP) Kota Palopo. Konsep dalam penelitian ini ada dua yaitu; Sistem Pelaporan Akuntansi Berbasis Akrual dan Implementasi Kebijakan Sistem Akuntansi Berbasis Akrual (Edward George III). Teknik pengumpulan data penelitian ini menggunakan metode observasi, dokumentasi, dan wawancara dari lima orang informan. Metode analisis data penelitian menggunakan Model interaktif dari Miles dan Huberman yang terdiri dari: (1) reduksi data; (2) pengumpulan data; (3) penyajian data; dan (4) penarikan atau verifikasi kesimpulan. Hasil penelitian ini menunjukkan bahwa implementasi sistem akuntansi berbasis akrual di DPMPTSP Kota Palopo sudah dilakukan dengan sangat memuaskan dan mendapatkan nilai implementasi akuntansi berbasis akrual sebesar 94.22\%. Sedangkan untuk kualitas pelaporan keuangan sudah sesuai dengan aturan yang telah ditetapkan oleh pemerintah yang bertujuan untuk menghasilkan laporan keuangan yang lebih dipercaya, lebih akurat, komprehensif, dan relevan untuk pengambilan keputusan ekonomi, sosial, dan politik.
\end{abstract}

\section{Pendahuluan}

Pemerintah mengeluarkan PP 24 Tahun 2005 tentang Standar Akuntansi Pemerintahan (SAP) setelah dua tahun UU 17 Tahun 2003 diundangkan,. SAP tersebut merupakan standar akuntansi pemerintahan pada masa transisi dari basis kas menuju basis akrual yang dinamakan cash toward accrual. Namun hingga akhir tahun 2008, lima tahun setelah amanat UU 17 Tahun 2003, pemerintah masih belum dapat menerapkan akuntansi berbasis akrual secara penuh (Kusmanadji, 2014). Baru pada tahun 2010 pemerintah mengeluarkan PP 71 Tahun 2010 tentang Standar Akuntansi Pemerintahan, yang meliputi SAP berbasis akrual dan SAP berbasis kas menuju akrual. Standar Akuntansi Pemerintahan sebagaimana amanat dari undang-undang nomor 71 tahun 2010 tentang standar akuntansi pemerintahan, bahwa setiap entitas pelaporan dan entitas akuntansi pada pemerintah pusat harus menerapkan basis akrual untuk penyusunan laporan keuangan pemerintah, mau tak mau semua pengelolaan keuangan pada satuan kerja pemerintah pusat harus mampu daerah untuk menerapkan basis akrual. Dalam menyikapi hal tersebut Dinas Penanaman Modal dan Pelayanan Terpadu Satu Pintu (DPMPTSP) Kota Palopo harus melakukan peningkatan kualitas profesionalisme Aparatur pengelola keuangan agar mampu beradaptasi dan menjalankan dengan perubahan tersebut, mampu menjalankan tugas secara professional, memegang teguh etika birokrasi dan mampu 
menghasilkan laporan keuangan yang akuntabel sesuai dengan peraturan perundangundangan, dalam rangka memberikan informasi yang benar, baik kepada atasan maupun kepada masyarakat Kota Palopo.

Pemerintah Daerah dan Satuan Kerja Perangkat Daerah (SKPD) sebagai entitas pelaporan dan entitas akuntansi berkewajiban menyelenggarakan sistem akuntansi untuk memenuhi amanat PP Nomor 71 tahun 2010 sehingga akan menimbulkan kebutuhan untuk menyesuaikan sistem akuntansi berbasis kas menuju akrual yang sedang diterapkan saat ini ke sistem akuntansi berbasis akrual. Dengan adanya penyesuaian tersebut akan berdampak pada perubahan atau penyesuaian sistem penatausahaan dan pelaporan keuangan pemerintah daerah sehingga pemerintah daerah perlu menyiapkan sumber daya yang memadai. PP No 71 tahun 2010 mengamanatkan bahwa penerapan akuntansi berbasis akrual secara penuh harus di terapkan pada tahun anggaran 2015. Pada tahun 2015 adalah tahun yang sangat krusial dalam bidang pelaporan keuangan pemerintahan, baik pemerintahan pusat maupun pemerintahan daerah, tidak terkecuali pada seluruh pemerintah sulawesi selatan. Hal tersebut adalah karena pada tahun 2015 terjadi perubahan basis akuntansi pada pemerintah provinsi dan seluruh pemerintah kabupaten/kota di wilayah sulawesi selatan, dari yang sebelumnya mengunakan sistem akuntansi berbasis kas menuju akrual menjadi menggunakan sistem akuntansi berbasis akrual (accrual basis), dan kemudian Permendagri nomor 31 tahun 2016 tentang pedoman penyusunan anggaran pendapatan dan belanja daerah tahun anggaran 2017.

Akhir-akhir ini, organisasi sektor public dituntut untuk terus melakukan upaya perbaikan dalam pengelolaan sumber daya publik untuk menghasilkan laporan keuangan yang berkualitas. Tata kelola pemerintah yang baik atau good governance merupakan komitmen Pemerintah Indonesia dalam mewujudkan birokrasi yang bersih, efektif dan efisien. Lemahnya tata kelola pemerintah yang baik (good governace) diistansi pemerintahan ditandai dengan tidak efektifnya organisasi dan birokrasi, rendahnya kualitas pelayanan terhadap publik, sulitnya pemberantasan korupsi, kolusi dan Nepotisme (KKN) serta kurangnya partisipasi masyarakat dalam pembangunan (Sulaeman et al. 2015). Sejalan dengan pendapat yang dikemukakan oleh Sedarmayanti (2013) bahwa good governance pada sektor publik diartikan sebagai suatu proses tata kelola pemerintahan yang baik, dengan melibatkan stakeholders, terhadap berbagai kegiatan perekonomian, social politik, dan pemanfaatan beragam sumber daya seperti sumber daya alam, keuangan, dan manusia bagi kepentingan yang dilaksanakan dengan menganut asas: keadilan, pemerataan, persamaan, efisiensi, transparansi, dan akuntabilitas. Maka dari itu, Dinas Penanaman Modal dan Pelayanan Terpadu Satu Pintu (DPMPTSP) Kota Palopo terus melakuan pengevaluasian terhadap sumber daya dalam pemerintahanya agar lebih efektif dan efesien dalam pelaporannya.

Kementerian keuangan menyelenggarakan permulaan (kick off) implementasi akuntansi pemerintahan berbasis akrual pada tanggal 4 Maret 2015, bertempat di Aula Mezzanine Gedung Djuanda I Kementerian Keuangan. Penyelenggaraan acara kick off implementasi akuntansi pemerintahan berbasis akrual ditujukan untuk menciptakan momentum awal penerapan implementasi akuntansi pemerintahan berbasis akrual serta guna menciptakan semangat dan komitmen kuat pada pimpinan Kementerian Negara/Lembaga terhadap implementasi akuntansi pemerintahan berbasis akrual dengan tetap mempertahankan peningkatan kualitas pelaporan keuangan (Kementerian Keuangan, 2015). Namun pada tanggal 30 Oktober 2015, Direktur Jenderal Perbendaharaan Kementerian Keuangan menerbitkan surat nomor S-9180/PB/ mnj2015 tentang Penyusunan Pseudo Laporan Keuangan Tahun 2015 yang menyatakan bahwa masih terdapat berbagai permasalahan dalam penyusunan Laporan Keuangan Kementerian Lembaga (LKKL) Semester I Tahun 2015 berkenaan dengan implementasi akuntansi berbasis akrual. Oleh karena itu perlu dilakukan evaluasi dan penelitian mendalam atas penerapan akuntansi berbasis akrual di DPMPTSP Kota Palopo.

\section{Tinjauan Pustaka}

2.1 Penerapan Sistem Laporan Keuangan Berbasis Akrual 
Berdasarkan Peraturan Pemerintah Nomor 71 tentang Standar Akuntansi Pemerintahan (SAP), Komponen-komponen yang terdapat dalam satu set laporan keuangan berbasis akrual terdiri dari laporan pelaksanaan anggaran (budgetary reports) dan laporan finansial. Laporan pelaksanaan anggaran adalah Laporan Realisasi Anggaran dan Laporan Perubahan Saldo Anggaran Lebih, sedangkan yang termasuk laporan finansial adalah Laporan Operasional, Laporan Perubahan Ekuitas, Neraca dan Laporan Arus Kas. Komponen-komponen laporan keuangan tersebut disajikan oleh setiap entitas pelaporan, kecuali Laporan Arus Kas yang hanya disajikan oleh entitas yang mempunyai fungsi perbendaharaan umum, dan Laporan Perubahan Saldo Anggaran Lebih yang hanya disajikan oleh Bendahara Umum Negara dan entitas pelaporan yang menyusun laporan keuangan konsolidasinya.

\subsection{Implementasi Sistem Pelaporan Keuangan}

Model implementasi kebijakan yang berspektif top down yang dikembangkan oleh George C. Edward III. Edward III menamakan model implementasi kebijakan publiknya dengan Direct and Indirect Impact on Implementation. Dalam pendekatan teori ini terdapat empat variabel yang mempengaruhi keberhasilan impelementasi suatu kebijakan, yaitu: 1. Komunikasi; 2. Sumberdaya; 3. Disposisi; dan 4. Struktur birokrasi (George C. Edward III, 1990).

1) Komunikasi

Variabel pertama yang mempengaruhi keberhasilan implementasi suatu kebijakan menurut Goerge C. Edward III (dalam Agustino), adalah komunikasi. Komunikasi, menurutnya sangat menentukan keberhasilan pencapaian tujuan dari implementasi kebijakan publik. Implementasi yang efektif terjadi apabila para pembuat keputusan sudah mengetahui apa yang akan mereka kerjakan.

Pengetahuan atas apa yang akan mereka kerjakan dapat berjalan apabila komunikasi berjalan dengan baik, sehingga setiap keputusan kebijakan dan peraturan impelementasi harus ditansmisikan (atau dikomunikasikan) kepada bagian personalia yang tepat. Selain itu, kebijakan yang dikomunikasikan pun harus tepat, akurat, dan konsisten. Komunikasi (atau pentransmisian informasi) diperlukan agar para pembuat keputusan dan para implementor akan semakin konsisten dalam melaksanakan setiap kebijakan yang akan diterapkan dalam masyarakat.

Menurut Usman (2006), terdapat tiga indikator yang dapat dipakai dalam mengukur keberhasilan variabel komunikasi yaitu : a) Transmisi; penyaluran komunikasi yang baik akan dapat menghasilkan suatu implementasi yang baik pula. Seringkali yang terjadi dalam penyaluran komunikasi adalah adanya salah pengertian (misscommunication). b) Kejelasan; komunikasi yang diterima oleh para pelaksana kebijakan (street-level-bureuarats) haruslah jelas dan tidak membingungkan (tidak ambigu/mendua) ketidakjelasan pesan kebijakan tidak selalu mengahalangi impelementasi, pada tataran tertentu, para pelaksana membutuhkan fleksibelitas dalam melaksanakan kebijakan. Tetapi pada tataran yang lain hal tersebut justru akan menyelewengkan tujuan yang hendak dicapai oleh kebijakan yang telah ditetapkan. c) Konsistensi; perintah yang diberikan dalam melaksanakan suatu komunikasi haruslah konsisten dan jelas untuk diterapkan atau dijalankan. Karena jika perintah yang diberikan sering berubah-ubah, maka dapat menimbulkan kebingungan bagi pelaksana di lapangan.

2) Sumber Daya

Variabel kedua yang mempengaruhi keberhasilan implementasi suatu kebijakan adalah sumber daya. Sumber daya merupakan hal penting lainnya dalam mengimplementasikan kebijakan, menurut Goerge C.Edward III (dalam Agustino, 2010).

Fattah (2008), indikator sumber daya terdiri dari beberapa elemen, yaitu: a) Staf; sumberdaya utama dalam implementasi kebijakan dalah staf. Kegagalan yang sering terjadi dalam implementasi kebijakan salah satunya disebabkan oleh karena staf yang tidak mencukupi, memadai, ataupun tidak kompeten di bidangnya. Penambahan jumlah staf dan implementor saja tidak cukup, tetapi diperlukan juga kecukupan staf dengan keahlian dan kemampuan yang diperlukan (kompeten dan kapabel) dalam mengimplementasikan kebijakan atau 
melaksanakan tugas yang diinginkan oleh kebijakan itu sendiri. b) Informasi; dalam implementasi kebijakan, informasi mempunyai dua bentuk, yaitu pertama informasi yang berhubungan dengan cara melaksanakan kebijakan. Implementor harus mengetahui apa yang harus mereka lakukan saat mereka diberi perintah. Kedua, informasi mengenai data kepatuhan dari para pelaksana terhadap peraturan dan regulasi pemerintah yang telah ditetapkan. Implementer harus mengetahui apakah orang yang terlibat di dalam pelaksanaan kebijakan tersebut patuh terhadap hukum. c) Wewenang; pada umumnya kewenangan harus bersifat formal agar perintah dapat dilaksanakan. Kewenangan merupakan otoritas atau legitimasi bagi para pelaksana dalam melaksanakan kebijakan yang ditetapkan secara politik. Ketika wewenang nihil, maka kekuatan para implementor dimata publik tidak terlegitimasi, sehingga dapat menggagalkan proses implementasi kebijakan. Tetapi dalam konteks yang lain, ketika wewenang formal tersebut ada, maka sering terjadi kesalahan dalam melihat efektivitas kewenangan. Disatu pihak, efektivitas akan menyurut manakala wewenang diselewengkan oleh para pelaksana demi kepentingannya sendiri atau demi kepentingan kelompoknya. d) Fasilitas; fasilitas fisik juga merupakan faktor penting dalam implementasi kebijakan. Implementor mungkin memiliki staf yang mencukupi, mengerti apa yang harus dilakukan dan memiliki wewenang untuk melaksanakan tugasnya, tetapi tanpa adanya fasilitas pendukung (sarana dan prasarana) maka implementasi kebijakan tersebut tidak akan berhasil.

3) Disposisi

Variabel ketiga yang mempengaruhi keberhasilan implementasi kebijakan adalah disposisi. Hal-hal penting yang perlu dicermati pada variabel disposisi, menurut Goerge C.Edward III (dalam Agustino, 2010), adalah : a) Pengangkatan birokrat; disposisi atau sikap pelaksana akan menimbulkan hambatanhambatan yang nyata terhadap implementasi kebijakan apabila personil yang ada tidak melaksanakan kebijakan-kebijakan yang diinginkan oleh pejabat-pejabat tinggi. Karena itu, pemilihan dan pengangkatan personil pelaksana kebijakan haruslah orang-orang yang memiliki dedikasi pada kebijakan yang telah ditetapkan. b) Insentif; Edward menyatakan bahwa salah satu teknik yang disarankan untuk mengatasi masalah kecenderungan para pelaksana adalah dengan memanipulasi insentif. Oleh karena itu, pada umumnya orang bertindak menurut kepentingan mereka sendiri, maka memanipulasi insentif oleh para pembuat kebijakan mempengaruhi tindakan para pelaksana kebijakan. Dengan cara menambah keuntungan atau biaya tertentu mungkin akan menjadi faktor pendorong yang membuat para pelaksana kebijakan melaksanakan perintah dengan baik.

4) Struktur birokrasi

Keberhasilan implementasi kebijakan publik adalah struktur birokrasi. Walaupun sumber daya untuk melaksanakan suatu kebijakan tersedia, atau para pelaksana kebijakan mengetahui apa yang seharusnya dilakukan, dan mempunyai keinginan untuk melaksanakan suatu kebijakan, kemungkinan kebijakan tersebut tidak dapat dilaksanakan atau direalisasikan karena terdapatnya kelemahan dalam struktur birokrasi. Kebijakan yang begitu kompleks menuntut adanya kerjasama banyak orang, ketika stuktur birokrasi tidak kondusif pada kebijakan yang tersedia, maka hal ini akan menyebabkan sumber daya-sumber daya menjadi tidak efektif dan menghambat jalannya kebijakan. Birokrasi sebagai pelaksana sebuah kebijakan harus dapat mendukung kebijakan yang telah diputuskan secara politik dengan jalan melakukan koordinasi dengan baik. Dua karakteristik, menurut Edward III, yang dapat mendongkrak kinerja struktur birokrasi/organisasi kearah yang lebih baik, yaitu dengan melakukan: a) standar operating prosedures (SOPs); adalah suatu kegiatan rutin yang memungkinkan para pegawai (atau pelaksana kebijakan / administrator / birokrat) untuk melaksanakan kegiatankegiatannya setiap hari sesuai dengan standar yang ditetapkan atau standar minimum yang dibutuhkan dan b) Fragmentasi; adalah upaya penyebaran tanggungjawab kegiatan kegiatan atau aktivitasaktivitas pegawai diantara beberapa unit kerja.

\section{Metode Penelitian}

Metode analisis dalam penelitian ini menggunakan metode kualitatif. Analisis data penelitian ini diperoleh dari hasil observasi 
dokumentasi dan wawancara yang didapatkan dari beberapa informan. Adapun informan dari penelitian ini terdiri dari lima orang dari bagian keuangan yang memiliki jabatan sebagai Kepala Divisi, Kepala bagian, Programer, Bendahara dan Staff. Adapun proses atau prosedur wawancara yang dilakukan yaitu (1) mengidentifikasi partisipan berdasarkan prosedur sampling yang dipilih (2) menentukan jenis wawancara yang digunakan dalam penelitian ini menggunakan jenis wawancara berstruktur. (3) merekam dan menulis pembicaraan selama peroses wawancara. (4) memberikan pertanyaan yang sudah disiapkan oleh informan.

Analisis data dilakukan dengan cara mengorganisasi data yang diperoleh kedalam sebuah kategori, menjabarkan data kedalam unit-unit, menganalisis data yang penting, menyusun atau menyajikan data yang sesuai dengan masalah penelitian dalam bentuk laporan dan membuat kesimpulan agar mudah untuk dipahami. Sesuai dengan jenis penelitian di atas, maka peneliti menggunakan model interaktif dari Miles dan Huberman untuk menganalisis data hasil penelitian. Aktivitas dalam analisis data kualitatif dilakukan secara interaktif dan berlangsung secara terusmenerus sampai tuntas, sehingga datanya sudah jenuh. Adapun komponen dari model interaktif yang digunakan yaitu, 1) reduksi data 2) pengumpulan data 3) penyajian data 4) penarikan atau verifikasi kesimpulan. Menurut Sugiono (2012) mengatakan bahwa uji keabsahan data dalam penelitian kualitatif meliputi uji credibility (Validitas internal), transferability (validitas eksternal), dependability (reabilitas), dan confirmability (objektivitas). Pada penelitian ini digunakan uji kredibilitas untuk menguji keabsahan data. Uji kredibilitas yang dilakukan dengan triangulasi. Triangulasi dalam keabsahan data, yaitu triangulasi sumber, triangulasi teknik, dan triangulasi waktu. Pada penelitian ini, peneliti menggunakan triangulasi teknik.

\section{Hasil Penelitian dan Pembahasan}

\subsection{Implementasi Kebijakan Sistem Pelaporan Keuangan Berbasis Akrual}

Implementasi SAP berbasis akrual dinilai dengan membandingkan antara kebijakan akuntansi yang tertuang dalam PMK 219
Tahun 2013 dan penerapannya. Tabel 1 menunjukkan nilai implementasi SAP berbasis akrual.

Berdasarkan tabel 1 diketahui bahwa DPMPTSP mendapatkan nilai hasil akhir implementasi sebesar 94,22\%. Berdasarkan pedoman umum evaluasi yang diatur dalam Permenpan-RB Nomor 12 Tahun 2015, nilai implementasi sebesar $94.22 \%$ masuk dalam kategori AA dengan interpretasi Sangat Memuaskan. Di satu sisi, nilai sebesar 94,22\% menunjukkan penerapan yang sangat baik, namun di sisi lain nilai tersebut menunjukkan bahwa masih terdapat kekurangan.

Tabel 1. Nilai Penerapan SAP Berbasis Akrual

\begin{tabular}{lc}
\hline \multicolumn{1}{c}{ Akun } & Skor \\
\hline Kas di Bendahara Pengeluaran & $100.00 \%$ \\
Kas Lainnya dan Setara Kas & $100.00 \%$ \\
Beban Dibayar di Muka & $100.00 \%$ \\
Bagian Lancar Tagihan Tuntutan & $100.00 \%$ \\
Perbendaharaan/Tuntutan Ganti Rugi & \\
Persediaan & $80.00 \%$ \\
Aset Tetap & $88.50 \%$ \\
Aset Tidak Berwujud & $80.00 \%$ \\
Aset Lain-lain & $100.00 \%$ \\
Utang Kepada Pihak Ketiga & $85.00 \%$ \\
Uang Muka dari KPPN & $100.00 \%$ \\
Utang Jangka Pendek Lainnya & $100.00 \%$ \\
Ekuitas & $100.00 \%$ \\
Pendapatan Bukan Pajak-LO & $100.00 \%$ \\
Beban Pegawai & $100.00 \%$ \\
Beban Persediaan & $90.00 \%$ \\
Beban Barang dan Jasa & $90.00 \%$ \\
Beban Pemeliharaan & $88.30 \%$ \\
Nilai Implementasi Akuntansi Berbasis & $94.22 \%$ \\
Akrual &
\end{tabular}

Sumber: Data Diolah (2019)

\subsection{Persediaan}

Berdasarkan hasil observasi, DPMPTSP baru mengakui dan mencatat Persediaan setelah terjadi pengeluaran kas dengan SP2D sebagai dokumen sumber. Ketidaksesuaian antara praktik dengan PMK 219 Tahun 2013 pada akun Persediaan terjadi dalam proses pengakuan. DPMPTSP juga melakukan pencatatan persediaan secara periodik setiap akhir bulan. Berdasarkan PMK 219 Tahun 2013, Persediaan seharusnya dicatat pada saat potensi manfaat ekonomi masa depan diperoleh dan mempunyai nilai atau biaya yang dapat diukur dengan andal yang didukung oleh bukti/dokumen yang dapat diverifikasi dan di dalamnya terdapat elemen harga barang persediaan sehingga biaya 
tersebut dapat diukur secara andal, jujur, dapat diverifikasi, dan bersifat netral, atau pada saat diterima atau hak kepemilikannya dan/atau kepenguasaannya berpindah dengan dokumen sumber yang digunakan sebagai pengakuan perolehan persediaan adalah faktur, kuitansi, atau Berita Acara Serah Terima (BAST).

Menurut HM "Ketidaktepatan waktu pengakuan Persediaan terjadi karena tidak terintegerasinya aplikasi yang digunakan. Di satu sisi, aplikasi SAIBA yang digunakan dalam penyusunan laporan keuangan mengakui Persediaan setelah terjadi pengeluaran kas dengan dokumen sumber berupa SP2D. Di sisi lain, aplikasi Persediaan yang digunakan dalam pengelolaan persediaan seharusnya sudah dapat melakukan pencatatan pada saat persediaan tersebut diterima".

Menurut JM "Tidak terintegrasinya kedua aplikasi tersebut disebabkan karena kedua aplikasi tersebut dikembangkan oleh pengembang yang berbeda. Keterlambatan pengakuan tersebut akan menimbulkan risiko tidak tercatatnya sebagian aset pemerintah".

\subsection{Aset Tetap}

Hal yang menjadi Permasalahan pada akun Aset Tetap terjadi pada tahap pengakuan. Sebagaimana akun Persediaan, ketidaksesuaian proses pengakuan pada akun Aset Tetap terjadi karena pencatatan baru dilakukan setelah diterbitkannya SP2D. Selain itu, terdapat hal-hal yang belum diungkapkan dalam CaLK. Sebagaimana yang terjadi pada akun Persediaan, keterlambatan pengakuan disebabkan oleh tidak terintegrasinya aplikasi SIMAK BMN dengan aplikasi SAIBA. Keterlambatan pengakuan tersebut juga akan membuat informasi Aset Tetap yang disajikan tidak akurat. Sementara itu, dalam proses penyajian dan pengungkapan pada akun Aset Tetap, PMK 219 Tahun 2013 mensyaratkan adanya hal lain yang perlu diungkapkan. Hal lain yang perlu diungkapkan tersebut adalah eksistensi dan batasan hak milik Aset Tetap dan jumlah komitmen untuk akuisisi Aset Tetap. Dalam laporan keuangannya, DPMPTSP tidak mengungkapkan hal tersebut. Tidak diungkapkannya suatu hal yang perlu diungkapkan dapat terjadi karena komunikasi yang kurang efektif. Seharusnya terdapat peraturan atau pedoman yang mengatur lebih rinci mengenai hal lain yang perlu diungkapkan dalam CaLK.

\subsection{Aset Tak Berwujud}

Permasalahan pada akun Aset Tak Berwujud juga terjadi pada tahap pengakuan. Sebagaimana yang terjadi pada akun Aset Tetap, keterlambatan pengakuan disebabkan oleh tidak terintegrasinya aplikasi SIMAK BMN dengan aplikasi SAIBA. Keterlambatan pengakuan tersebut juga akan membuat informasi Aset Tak Berwujud yang disajikan tidak akurat. Sementara itu, dalam proses penyajian dan pengungkapan pada akun Aset Tak Berwujud, PMK 219 Tahun 2013 mensyaratkan diungkapkannya masa manfaat tiap aset tak berwujud beserta metode amortisasi yang digunakan, nilai tercatat bruto, jumlah amortisasi yang telah dilakukan dan nilai buku aset tak berwujud, serta pengungkapan mengenai penambahan maupun penurunan nilai pada awal dan akhir periode, termasuk penghentian dan pelepasan aset tak berwujud. Namun, peraturan tersebut tidak mengatur lebih jelas mengenai metode amortisasi dan cara perhitungannya sebagaimana pada bagian Aset Tetap. Akibatnya, terdapat hal yang tidak diungkapkan dan tidak menggambarkan nilai Aset Tak Berwujud yang sebenarnya.

\subsection{Utang Kepada Pihak Ketiga}

Menurut PMK 219 Tahun 2013, Utang Kepada Pihak Ketiga diakui pada saat Pemerintah telah menerima hak atas barang/jasa, termasuk barang dalam perjalanan yang telah menjadi haknya. Namun dalam praktiknya hal itu tidak dapat di lakukan. Utang Kepada Pihak Ketiga baru dicatat pada akhir periode pelaporan dengan menyusun jurnal penyesuaian akrual untuk mengakui adanya kewajiban dan beban. Dalam rangka menyusun jurnal penyesuaian, penyusun laporan keuangan harus mengidentifikasi dan menginventarisir barang/jasa yang belum dibayarkan sampai dengan akhir periode pelaporan. Menurut Badan Pemeriksa Keuangan (BPK) menyatakan dalam Laporan Hasil Pemeriksaan (LHP) Kinerja Atas Pengendalian Internal Terhadap Pelaporan Keuangan Pemerintah Pusat Berbasis Akrual, hal itu dapat meningkatkan risiko tidak tercatatnya seluruh hak dan kewajiban 
pemerintah yang layak diakui sebagai beban/ pendapatan dalam satu periode pelaporan.

Praktik tersebut diakibatkan oleh aplikasi SAIBA yang belum memadai dan tidak dapat mengakomodir pencatatan transaksi pada saat diterimanya hak atau timbulnya kewajiban. Selain itu, BPK juga menyatakan bahwa Menteri Keuangan belum membuat aturan yang jelas mengenai dokumen sumber pendukung sebagai dasar pencatatan jurnal penyesuaian. PMK 219 Tahun 2013 tidak mengatur secara rinci dokumen sumber yang digunakan.

\subsection{Beban Operasional}

Sebagaimana permasalahan pada akunakun sebelumnya, permasalahan dalam tahap pengakuan pada sebagian besar akun beban operasional terjadi karena aplikasi SAIBA yang belum memadai dan tidak dapat mengakomodir pencatatan transaksi pada saat diterimanya hak atau timbulnya kewajiban. Keterlambatan tersebut dapat meningkatkan risiko tidak tercatatnya kewajiban pemerintah.

Sementara itu, untuk akun Beban Persediaan, ketidaksesuaian proses pengakuan terjadi karena kurangnya SDM. Menurut PMK 219 Tahun 2013, beban diakui saat terjadinya konsumsi aset non kas dalam kegiatan operasional. Artinya, Beban Persediaan seharusnya dicatat pada saat terjadi mutasi keluar, atau penggunaan barang persediaan berdasarkan Surat Perintah Mengeluarkan Barang (SPMB).

Menurut FH "lima laporan yang belum sepenuhnya menggunakan sistem berbasis akrual di karenakan kurangnya SDM yang kompeten dibidang akuntansi"

Hal ini sesuai dengan penelitian Herwiyanti et al. (2017) yang mengatakan bahwa penerapan sistem akuntansi akrual di Itjen Kemenkeu sudah dilakukan dengan sangat memuaskan, yang ditunjukkan dengan nilai sebesar 93,40\%. Meskipun penerapan sistem pelaporan keuanan berbasis akrual dilakukan dengan baik, namun masih terdapat kendala-kendala yang dihadapi. Hal ini pula sesuai dengan penelitian yang dilakukan Dollah et al. (2017).

\subsection{Berdasarkan Implementasi Kebijakan (George C. Edward III).}

- Aspek Komunikasi
Dalam menerapkan akuntansi berbasis akrual, DPMPTSP berpedoman pada SAP berbasis akrual yang ditetapkan dalam bentuk peraturan pemerintah. Agar peraturan tersebut dapat diketahui dan dilaksanakan, maka dilakukan sosialisasi kepada seluruh penyusun laporan keuangan. Seluruh informan dan dokumentasi mengakui bahwa sosialisasi SAP berbasis akrual telah dilakukan. Sosialisasi tersebut dilakukan baik secara langsung maupun tidak langsung.

"Menurut FH sosialisasi secara langsung dilakukan pada level pimpinan dalam skala nasional. Sementara itu, pada tataran teknis di tingkat pelaksana, sosialisasi dilakukan secara tidak langsung. Menurut para pelaksana yang menjadi informan dalam penelitian ini, sosialisasi tidak langsung dilakukan melalui surat. Namun untuk mempercepat proses sosialisasi, surat tersebut di-scan dan dikirim via email kepada masing-masing satuan kerja".

Sejauh ini, seluruh peraturan dan pedoman yang telah diterbitkan dalam rangka penerapan akuntansi berbasis akrual sudah dianggap memadai oleh sebagian besar informan. Mereka menilai peraturan dan pedoman tersebut mudah untuk dipahami dan dilaksanakan. Peraturan dan pedoman tersebut biasanya dilampirkan dengan petunjuk teknis yang sangat rinci sehingga para pelaksana tinggal mengikuti langkah-langkahnya saja.

Peraturan dan pedoman yang dilengkapi dengan petunjuk teknis yang sangat rinci tersebut dapat menghemat waktu dan dana para penyusun kebijakan sehingga tidak perlu dilakukan sosialisasi khusus untuk setiap pedoman dan peraturan yang diterbitkan. Bahkan Informan 4 mengatakan bahwa untuk peraturan yang pelaksanaannya menggunakan aplikasi atau sistem informasi, pelaksanaan aturan tersebut biasanya sudah dimasukkan ke dalam sistem sehingga para pelaksana hanya diminta untuk update aplikasinya.

"Menurut MS salah satu kekurangan sosialisasi tidak langsung adalah komunikasi yang dilakukan satu arah. Untuk mengatasi hal itu, apabila ada pertanyaan atau ketidakpahaman mengenai peraturan dan pedoman yang disosialisasikan, maka pelaksana kebijakan dapat berkomunikasi langsung dengan programer" 
Di luar aturan main dan pedoman teknis untuk menerapkan SAP Akrual, hampir seluruh informan sepakat bahwa kebijakan akuntansi berbasis akrual yang diterapkan saat ini belum mencerminkan praktik akuntansi berbasis akrual. Mereka mengatakan bahwa pengakuan dan pencatatan atas Pendapatan Laporan Operasional (LO), Beban, dan Aset dilakukan pada saat terjadi penerimaan dan pengeluaran ke dan dari kas negara. Pelaksanaan akrual hanya dilakukan pada saat pelaporan dengan melakukan jurnal penyesuaian pada akhir periode akuntansi.

Pelaksanaan akuntansi berbasis akrual yang dianggap belum akrual tersebut ternyata menjadi temuan oleh Badan Pemeriksa Keuangan dalam Laporan Hasil Pemeriksaan (LHP). Menurut Badan Pemeriksa Keuangan (BPK), praktik tersebut dapat menimbulkan risiko tidak tercatatnya seluruh hak dan kewajiban Pemerintah yang layak diakui sebagai aset, pendapatan, dan beban dalam satu periode akuntansi.

\subsection{Aspek Sumber Daya}

Sumber daya merupakan salah satu faktor penting dalam pelaksanaan implementasi kebijakan. Peran sumber daya manusia dan aplikasi pendukung menjadi faktor penting dalam mengimplementasikan SAP berbasis akrual dalam penyusunan laporan keuangan sehingga bisa menghasilkan laporan keuangan basis akuntansi akrual dengan kualitas informasi yang baik. Dalam penelitian ini peneliti menemukan 2 (dua) kendala yang berkaitan dengan sumber daya yaitu belum cukup memadainya SDM pengelola keuangan, dan banyaknya aplikasi yang datanya belum terintegrasi satu dengan yang lainnya.

Pertama, kendala berkaitan dengan SDM yang belum cukup memadai baik secara kualitas dan kuantitas, baik yang ada pada entitas pelaporan yaitu SKPKD dan entitas akuntansi pada satuan kerja perangkat daerah. Kedua, kendala yang berkaitan dengan sumber daya manusia pengelola aset yang ada pada SKPD yang sering berganti-ganti sehingga pengelola aset tersebut tidak mengetahui asetaset apa saja yang dimiliki oleh SKPD tersebut dan aset-aset mana saja yang telah dicatat dan belum dicatat pada aplikasi Simda Barang Milik Daerah menjadi salah satu kendala dalam implementasi SAP berbasis akrual dalam penyusunan laporan keuangan.

Sumber daya merupakan faktor penting yang mempengaruhi implementasi kebijakan, SDM yang belum memadai dari sisi jumlah dan kemampuan akan mengakibatkan implementasi suatu kebijakan tidak akan berjalan dengan baik, begitupun dengan aplikasi pendukung implementasi suatu kebijakan dimana aplikasi yang ada seharusnya bisa membantu proses pelaksanaan implementasi kebijakan. Untuk itu pemerintah Kabupaten Bolaang Mongondow Utara memerlukan suatu manajemen sumber daya manusia yang baik dan kemudahan didalam pemanfaatan aplikasi untuk memudahkan suatu pekerjaan.

Kedua, Berdasarkan database kepegawaian, seluruh pelaksana kebijakan SAP berbasis akrual belum pernah mengikuti diklat terkait pengelolaan keuangan dan penyusunan laporan keuangan. Namun, menurut FH yang merupakan salah satu pelaksana kebijakan mengaku pernah mengikuti workshop yang diadakan oleh Pusat Pendidikan dan Pelatihan Anggaran dan Perbendaharaan. Sementara itu, pelaksana lainnya yang belum pernah mengikuti diklat mengaku dapat melaksanakan tugas dan tanggung jawabnya karena diajarkan oleh pelaksana sebelumnya. Walaupun belum pernah mengikuti diklat khusus SAP berbasis akrual.

"Meurut FH menganggap para pelaksana telah kompeten dan dapat melaksanakan tugasnya dengan baik. Hal ini dikarenakan mereka sebelumnya sudah pernah mengikuti diklat tentang pengelolaan keuangan dan penyusunan laporan keuangan",

Dalam menerapkan SAP Berbasis Akrual, DPMPTSP telah menggunakan teknologi informasi sebagaimana dikatakan oleh seluruh informan. Aplikasi tersebut terdiri dari aplikasi Sistem Akuntansi Basis Akrual (SAIBA), Sistem Aplikasi Satker (SAS), Sistem Informasi Manajemen dan Akuntansi (SIMAK BMN), Persediaan, e-Rekon, dan Online Monitoring Sistem Perbendaharaan dan Anggaran Negara (OM SPAN).

Dari keenam aplikasi tersebut, tiga diantaranya merupakan aplikasi yang baru digunakan pada tahun 2015, yaitu SAIBA, e- 
Rekon, dan OM SPAN. Sementara, aplikasi lainnya telah digunakan sebelum diterapkannya SAP Akrual. Walaupun telah digunakan lebih dari tiga tahun, namun hampir seluruh informan menganggap bahwa aplikasiaplikasi tersebut masih memiliki beberapa kendala. Kendala tersebut diantaranya adalah ketidakakuratan nilai Barang Milik Negara (BMN) yang disajikan dalam SIMAK BMN dan kelemahan pengendalian dalam aplikasi Persediaan.

Banyaknya aplikasi yang digunakan untuk mendukung penyusunan laporan keuangan menyebabkan proses implementasi akuntansi berbasis akrual menjadi tidak efisien. Selain itu juga dapat meningkatkan risiko salah saji. Oleh karena itu perlu dikembangkan suatu aplikasi penyusun laporan keuangan yang terintegrasi. Baik terintegrasi secara internal, maupun secara eksternal dengan Bendahara Umum Negara.

"Menurut JM percaya bahwa permasalahan terkait aplikasi yang digunakan saat ini dapat diselesaikan dengan aplikasi terintegrasi. Sampai saat ini, aplikasi terintegrasi yang dinamakan SAKTI sudah dalam tahap piloting (tahap percontohan), dan dapat digunakan setelah tahapan piloting berhasil dilaksanakan. Terkait dengan sumber daya keuangan, penerapan SAP berbasis akrual tidak memberikan dampak yang signifikan dalam anggaran DPMPTSP."

"Menurut HM hal itu disebabkan oleh transaksi yang tidak terlalu rumit dan kompetensi SDM yang memadai. Kenaikan biaya dalam rangka penerapan akuntansi berbasis akrual hanya disebabkan oleh penambahan jadwal konsolidasi yang semula hanya dilakukan semesteran, pada tahun 2015 dilakukan triwulanan dan ditambah dengan adanya kebijakan penyusunan prosedur laporan keuangan mulai bulan Oktober sampai dengan akhir periode pelaporan"

Dalam rangka mendukung penerapan SAP berbasis akrual, para informan mengatakan bahwa sarana dan prasarana yang disediakan sudah cukup. Berdasarkan hasil observasi, sarana dan prasarana yang disediakan antara lain 1 buah meja, kursi dan perangkat komputer yang memadai untuk setiap staf, 1 buah laptop, 1 buah alat scanner, dan satu buah printer.

\subsection{Aspek Komitmen Organisasi}

Mulai dari penyusun sampai dengan pelaksana kebijakan, keberhasilan implementasi SAP berbasis akrual sangat ditentukan oleh besarnya dukungan dan komitmen dari seluruh pihak. DJPB sebagai penyusun dan penanggung jawab kebijakan telah melakukan penguatan komitmen dengan para pengambil keputusan tertinggi pada masing-masing instansi kementerian negara/ lembaga dan pemerintah daerah, serta stakeholder kunci lainnya. Rangkaian kegiatan yang telah dilakukan dalam rangka penguatan komitmen ini adalah high level stakeholder meeting, deklarasi implementasi akuntansi berbasis akrual, dan sosialisasi kebijakan.

Penguatan komitmen tersebut berjalan dengan efektif di Kementerian Keuangan. Rocankeu sebagai pembina dan pengambil keputusan tertinggi terkait dengan akuntansi dan pelaporan di Kementerian Keuangan telah menunjukkan langkah konkret dalam mendukung penerapan SAP berbasis akrual. Langkah dukungan yang telah dilakukan adalah penerbitan buku-buku dan surat edaran sebagai pedoman dan petunjuk penerapan, dan helpdesk perencanaan dan keuangan untuk meningkatkan komunikasi dan koordinasi dengan pelaksana kebijakan. Sementara itu, DPMPTSP sebagai pelaksana kebijakan telah menyatakan dukungannya sebagaimana dikatakan oleh hampir seluruh informan. Sebagian dari mereka menganggap bahwa basis akrual merupakan basis akuntansi yang lebih baik dari basis akuntansi kas yang digunakan selama ini, sedangkan sebagian yang lain menganggap hal itu merupakan salah satu upaya dalam mewujudkan kepatuhan terhadap peraturan yang ada.

\subsection{Aspek Struktur Birokrasi}

Salah satu aspek struktural yang paling dasar dari suatu organisasi adalah prosedur kerja standar (SOP). DPMPTSP telah memutakhirkan SOP dalam rangka penerapan SAP berbasis akrual sebagaimana yang disampaikan oleh Informan 1dan Informan 5. Penuturan dari Informan 2 dan Informan 3 didukung oleh bukti dokumen. Dokumen berupa SOP yang didapatkan dari Bagian Organisasi dan Analisis Hasil Pemeriksaan (BOAHP) yang berwenang menerbitkan SOP masih tertanggal 27 Desember 2013 dan masih 
menggunakan basis cash toward accrual. Walaupun begitu, SOP tersebut tidak menjadi penghambat dalam implementasi SAP berbasis akrual. Sifat kedua dari struktur birokrasi yang berpengaruh dalam pelaksanaan kebijakan adalah fragmentasi organisasi. Tanggung jawab atas suatu kebijakan sering kali dipisah dan tersebar diantara beberapa unit dalam organisasi. Pemisahan fungsi dan wewenang juga merupakan prosedur yang direkomendasikan oleh pengendalian internal.

"Menurut MD yang masih aktif di Subbagian Akuntansi dan Perpajakan, koordinasi dengan subbagian Perbendaharaan dapat dikatakan baik, meskipun ada sebagian laporan yang belum menggunakan sistem berbasis akrual. Hal itu disebabkan oleh kurangnya SDM. Namun, hal itu pula membuat hubungan semakin baik dan salin bahu-membahu antar bagian”.

Berdasarkan dari pembahasan implementasi kebijakan George C. Edward III dapat diketahui bahwa implementasi kebijakan tersebut mampu dijadikan sebagai pedoman dalam penerapan sistem pelaporan keuangan berbassis akrual.

Hal ini juga serupa dengan penelitian oleh Surepno (2015) yang menyatakan bahwa Keberhasilan penerapan akuntansi akrual pemerintah Semarang didukung oleh empat strategi utama, yaitu komitmen manajemen, pengembangan peraturan, pengembangan sistem informasi dan pengembangan sumber daya manusia. Selanjutnya berdasarkan kesimpulan dari para pelaksana menunjukkan bahwa akuntansi akrual memiliki peran strategis dalam meningkatkan transparansi dan akuntabilitas melalui pelaporan keuangan.

\section{Kesimpulan}

Berdasarkan hasil penelitian, dapat ditarik kesimpulan sebagai berikut: Penerapan sistem akuntansi akrual di DPMPTSP sudah dilakukan dengan sangat memuaskan dan mendapatkan nilai sebesar 94.22\%. meskipun demikian masih ada komponen yang belum menggunakan sistem pelaporan angkuntasi berbasi akrual yaitu persedian, aset tetap, aset tidak berwujud, utang kepada pihak ketiga dan beban operasional.

Implementasi sistem akuntansi pemerintahan berbasis akrual dalam meningkatkan kualitas pelaporan pemerintahan pada Dinas Penanaman Modal dan Pelayanan Terpadu Satu Pintu Kota Palopo, peneliti menyimpulkan bahwa kualitas pelaporan di kantor DPMPTSP Kota Palopo sudah sesuai dengan aturan yang telah ditetapkan oleh pemerintah yang dimana pemerintah bertujuan untuk menghasilkan laporan keuangan yang lebih dipercaya, lebih akurat, komprehensif, dan relevan untuk pengambilan keputusan ekonomi, sosial, dan politik. Hal ini di dukung dengan adanya bukti nyata bahwa DPMPTSP Kota Palopo telah antusias mengimplementasikan sistem akuntansi berbasis akrual dalam meningkatkan kualitas pelaporan pemerintahan sebagiamana yang peneliti dapatkan dilapangan dan didukung rincian anggaran yang telah di manfaatkan untuk menggunakan sistem ini

\section{Daftar Pustaka}

Agustino. (2010). Implementasi Kebijakan Publik Model Van Meter dan Van Horn. Jakarta: Rajawali Press.

Dollah, K., Saerang, D.P.E., dan Manossoh, H. (2017). Analisis Implementasi Standar Akuntansi Pemerintahan Berbasis Akrual Pada Pemerintah Kabupaten Bolaang Mongondow Utara. Jurnal Riset Akuntansi dan Auditing "Goodwill”. Vol. 8, No.1.

Edward III, George C (edited) (1990). Public Policy Implementing. Jai Press Inc, LondonEngland. Goggin, Malcolm L et al.

Herwiyanti, E., Sukirman, dan Aziz, F.S. (2017). Analisis Implementasi Akuntansi Berbasis Akrual pada Inspektorat Jenderal Kementerian Keuangan. Jurnal Akuntansi dan Keuangan, Vol. 19, No. 1.

International Financial Reporting Standard. (2015). Sebuah Tinjauan Etika Profetik. Departemen Akuntansi Fakultas Ekonomi Universitas Kanjuruhan. Malang.

Kusmanadji. (2014). Penerapan Basis Akrual untuk Pelaporan Keuangan Pemerintah: Perkembangan Global dan Perjalanan Indonesia Menuju Penerapan Basis Akrual Penuh pada 2015. Jurnal Informasi Keuangan dan Akuntansi Infoartha, 3 (12), $1-12$

Republik Indonesia. (2003). Undang-Undang Nomor 17 Tahun 2003 tentang Keuangan Negara. Tambahan Lembaran Negara RI 
Tahun 2003 Nomor 4286. Sekretariat Negara. Jakarta.

Republik Indonesia. (2005). Peraturan Pemerintah Nomor 24 Tahun 2005 tentang Standar Akuntansi Pemerintahan, Tambahan Lembaran Negara RI Tahun 2005 Nomor 4503. Sekretariat Negara. Jakarta.

Republik Indonesia. (2010). Peraturan Pemerintah Nomor 71 Tahun 2010 tentang Standar Akuntansi Pemerintahan, Tambahan Lembaran Negara RI Tahun 2010 Nomor 5165. Sekretariat Negara. Jakarta.

Republik Indonesia. (2013). Peraturan Menteri Keuangan RI Nomor 219/PMK.05/2013 tanggal 31 Desember 2013 tentang Kebijakan Akuntansi Pemerintah Pusat.

Republik Indonesia. (2015). Peraturan Menteri Pemberdayaan Aparatur Negara dan Reformasi Birokrasi RI Nomor 12 Tahun 2005 tanggal 2 Juli 2015 tentang Pedoman Evaluasi atas Implementasi Sistem Akuntabilitas Kinerja Instansi Pemerintah,
Berita Negara RI Tahun 2015 Nomor 986. Jakarta.

Sedarmayanti. (2013). Reformasi Administrasi Publik, Reformasi Birokrasi, dan Kepemimpinan Masa Depan (Mewujudkan Pelayanan Prima dan Kepemerintahan yang Baik). Bandung : PT. Refika Aditama Bandung.

Sugiono. (2012). Metode Penelitian Pendidikn Pendekatan Kuantitatif, Kualitatif dan $R \& D$. Bandung: Alfabeta.

Sulaeman, Hamid, A., dan Yunus, M. (2015). Pengaruh Penerapan Good Corporate Governance Terhadap Kinerja Pegawai Dan Dampaknya Terhadap Kinerja Dinas Pertanian Dan Peternakan Kabupaten Bireuen. Jurnal Manajemen Pascasarjana Universitas Syiah Kuala. 4 (4). 112-121.

Surepno. (2015). The Key Success And Strategic Role Of Accrual Based Accounting Implementation. Journal The WINNERS 16(2). 142-151. 